\title{
Western Literature on Stupidity Reviewed
}

\author{
James FW*
}

USA

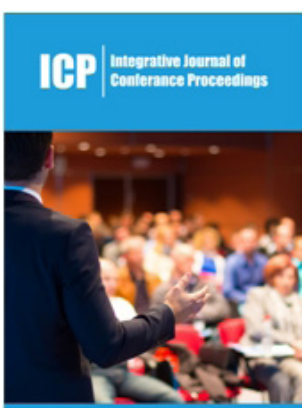

*Corresponding author: James FW, East Marion, USA

Submission: 想 May 13, 2019

Published: 眥June 06, 2019

Volume 1 - Issue 4

How to cite this article: James FW. Western Literature on Stupidity Reviewed. Int J Conf Proc.1(4). ICP.000516.2019.

Copyright@ James FW, This article is distributed under the terms of the Creative Commons Attribution 4.0 International License, which permits unrestricted use and redistribution provided that the original author and source are credited.

\begin{abstract}
This review of the literature on stupidity demonstrates it has been and is a topic of interest among literati from Greek and Biblical times to the present. Recent writings on the topic are mostly anecdotal and with two exceptions indicate a lack of scientific analysis in the phenome-non.
\end{abstract}

\section{Introduction}

Considering how little intelligence and how much stupidity there is, it really is incredible that the extent imbalance regarding these two phenomena in the scientific literature has existed for so long. Whatever the cause for this condition, it cannot be that stupidity is not a fit topic for scientific investigation because if it is not, then neither is intelligence. However, the one is totally neglected and the other virtually pounded into the ground. If we really want to have a full understanding of the human experience, we will finally have to acknowledge, examine and finally understand that which is both embarrassing and shameful. As an operative definition of stupidity, it may be regarded as the learned inability to learn: That is a normal, dysfunctional learning process which occurs when a schema formed by linguistic biases and social norms acts via the neurotic paradox to establish a positive feedback system which becomes first self-sustaining and then renders behavior irrelevant to the environment by carrying detached actions to maladaptive excesses. Fortunately, knowledge of stupidity is not limited to what historians and psychologists have not written about it. Herodotus noted that man was robbed of reason by Infatuation. Of course, in ancient Greece deities were responsible for everything, and in this matter, it was the goddess Ate who was responsible for infatuation, mischief, delusion and folly [1] apparently everything contributing to maladaptation but stupidity. She rendered her victims in capable of rational choice and blind to distinctions of morality and expedience (N.B. this moral dimension of Ate's influence). Biblically, the $14^{\text {th }}$ Psalm begins with a reference to an impious fool, and stupid men are condemned in Pro-verbs 7-8, although stupidity is personified as a lady (9:13). Wisdom, which starts with fear of the Lord (Psalm 111:10), and folly are compared in Ecclesiastes 7-11. Wisdom and knowledge are God given (2:26), but the reader is advised not to get overwise (7:16-17). This unlike li-hood is, presumably, because the fool and wise man-who will not be able to discover knowledge and find truth on his own (8:16-17) since wisdom is beyond his grasp (7:24) end up even (i.e., dead) [2]. In the Christian tradition generally, stupidity, blunder and folly were diplomatically glossed over by Jesus [3] in deference to the sensibilities of the members of his flock, who were remarkably ignorant [4] if not foolish [5]. Indeed, in his sermon on the mount, Jesus has been accused of promoting stupidity, docility and blind obedience in his followers [6]. With membership in the denomination dependent on the acceptance of a savior who was born of a virgin and rose from the dead, Christians are often regarded as fools by the wise of the world [7] although specifically advised not to engage in stupid banter nor to be fools [8]. Among themselves, criticism of human idiocy was discouraged so they came to regard the truth about a fool as a type of indecent exposure and most definitely taboo [9]. What other major religions of the world have to say about stupidity will not become clear until the beckoning field of comparative stupidity comes to flower, but the christian Don't ask; don't answer attitude certainly contributes to the nearly empty shelves in Western libraries where the scores/hundreds of books on stupidity should be. 


\section{Literature}

Those shelves are, fortunately, only Nearly empty, because despite the taboo, there have been a few pioneers who dared delve into the topic. First, of course, there were a couple of Germans. In 1909, Dr. Leopold Löwenfeld had Über die dummheit published. In this work, stupidity was not defined from a medical viewpoint, but rather its broad forms were classified as multidimensional functional failings of a faulty intellect-meaning dullness, weak character, inattention, misperception, poor judgment, clumsy associations, bad memory, etc. As might be expected, one of the sexes and one of the races was less stupid than the others, and although the book was updated in 1921, even World War I could not shake the author's conviction about the sexual/racial distribution of stupidity. He might well have inferred that white men were superior in stupidity, but for some reason, he not too objectively concluded instead everyone else was generally inferior in intellect. Following Leopold's lead, Max Kemmerich had Ausder Geschichte der mens chlichen Dummheit published in 1912. A Teutonic cure for insomnia, this work examines stupidity in a Biblical context and is essentially an attack on established religions. Max's emphasis on a belief system was well placed, but his work is intolerantly narrow in that he recognized the Holy Bible as the only legitimate standard for belief and behavior. In 1919, psychologist Charles Richet had L-homme stupide published. He dodged the issue of defining or classifying stupidity but dealt with the idiocies of drugs, wealth, feudalism, slavery, war, fashion, semantics, superstitions, etc. This is more a witty compilation of thoughts and examples than a scientific treatment of the phenomenon and ranged so far afield that some subjects bear only a tenuous connection with the topic. Dr. István Ráth-Végh, a retired Hungarian judge, contributed three books to the shelves. Like most other contributions, they are neither comprehensive nor analytical but do comprise 800 pages of source material for any reader of Hungarian in need of examples of idiocy grouped under convenient headings. Published at the rate of one per year from 1938 through 1940, only the first found its way into English: From the History of Human Folly (1963). The first book in English on the topic was A Short Introduction to the History of Human Stupidity (1932), by Walter Pitkin. Like many books, it was misnamed, being really a breezy essay on human folly, and failed, unfortunately, to generate any general interest in the topic. That year, Barbara Swain's Fools and Folly during the Middle Ages and The Renaissance also appeared, thoroughly covering the topic during the given time frame. Then in 1959 came Paul Tabori's The Natural Science of Stupidity-a superficial if entertaining collection of anecdotes culled from his-tory-and in 1970 John Fischer's general cultural review The Stupidity Problem, and Other Harassments.

In 1986, Dr James F Welles's ground-breaking Understanding Stupidity appeared. It opined that, conrary to Darwinian thinking, human culture is not adaptive-indeed, is maladaptive. Each civilization arises in response to certain problems, which it addresses, but in doing so, it sets a pattern which it cannot overcome and so too passes. Individuals display the same behavioral trait with the same result. Two years later, Dr. Welles was back with The Story of Stupidity-a review of Western history based on the new perspective of maladaptation as the common feature of human behavior. From Greece through to the end of the 20th century, and subsequently extended in later writings to the early $21^{\text {st }}$, he wins the reader over by showing the same pattern of behavior in age after age. The reader comes to realize the universality of the message when turning on the evening news or checking the internet. The commercial success of Forrest Gump and Beevis and Butthead led to a spat of intellectually vapid books on stupidity. However, in 2002, Dr. Robert Sternberg's misnamed volume Why Smart People Can Be So Stupid appeared-being not about stupidity but about the related but slightly differently defined topic of foolishness. It suffered from the fragmentation inherent in most edited works, but it did present a lot of research data consistent with the phenomenon of stupidity as well as provide an element of welcomed intellectual legitimacy to the topic by virtue of the title of its author. Although the term Stupidity does not appear in the title, Groupthink (1982), by Irving L. Janis, belongs on the shelves next to the volumes just cited. It is concerned with a specific cause of stupidity but has some general value to anyone interested in the topic and provides several good case studies of how leaders make both faulty and sound decisions. Finally, Barbara Tuchman's book The March of Folly (1984) rates a place with the others. Although she honors the reigning taboo against use of the word Stupidity, preferring the cumbersome Wooden headedness and news peakish Unwisdom, her book provides more case studies of leaders caught up in themselves. In fact, she made a summary statement of stupidity with the perceptive comment, Wooden headedness, the source of self-deception, is a factor that plays a remarkably large role in government. It consists in assessing a situation in terms of pre-conceived fixed notions while ignoring or rejecting any contrary signs and thus acting according to wishes without allowing one's behavior to be affected by unwelcome facts [10].

\section{Conclusion}

From Greek and Biblical times to the computer era, interest in stupidity has been constant if a muted sidelight in Western literature.

\section{References}

1. Tuchman B (1984) The march of folly. Knopf NY, USA, p. 46.

2. Koheleth C (2004) Ecclesiastes. 235BC 2: 16-17.

3. Matthew. In the King James Holy Bible, the quotation is: Whoever shall say, 'Thou fool', shall be in danger of hell fire." The New English Bible softens this considerably: "...if he sneers at him (i.e., his brother) he will have to answer for it in the fires of hell." Regardless of which translation is more accurate, it was the wording and image in the older version which dominated thinking and shaped our attitudes and values for the past 400 years if not before $5: 22$.

4. Ripley G (1839) Letters on the latest form of infidelity. USA, pp. 98-99.

5. Snow E (1944) Celsus. 178. True Word. Quoted in Origines Adamantius's Against Celsus; early $3^{\text {rd }}$ century. And the tradition continued until at least 1717, when pirate Samuel Bellamy, who, in a fit of righteousness, compared his freedom favorably to the slavish conditions of those who put their faith in parsons who neither practice nor believe what they preach to knuckleheaded fools.

6. Holbach PH (1999) Histoire critiques de Jesus christ, preface, in oeuvres philophiques completes. Alive, Paris, pp. 726-735. 
7. Scalia A (2007) Undated statement at a knight of columbus meeting cited in the nine by J Toobin. Doubleday New York, USA, p. 200.

8. Ephesians. 62 A.D. 5:4 and 5:17. This section is loaded with canny advice about how to be-like wives are subject in everything to husbands, who should love their wives as they love their own bodies, some parts of which are quite loveable.
9. Pitkin W (1932) A short introduction to the history of human stupidity. Simon and Schuster New York, USA, p. 25.

10. Tuchman, op it, 7

For possible submissions Click below:

\section{Submit Article}

